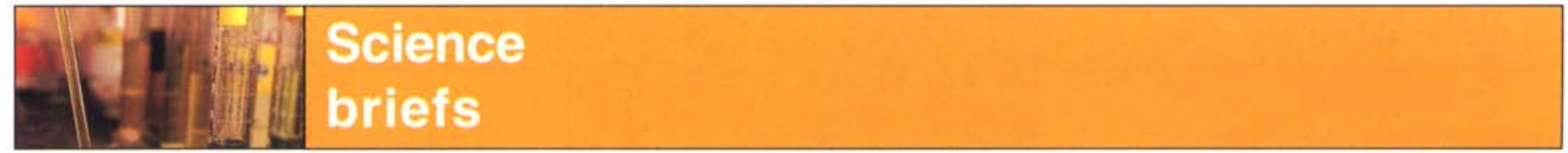

\title{
UC scientists study Pierce's disease, vineyard expansion
}

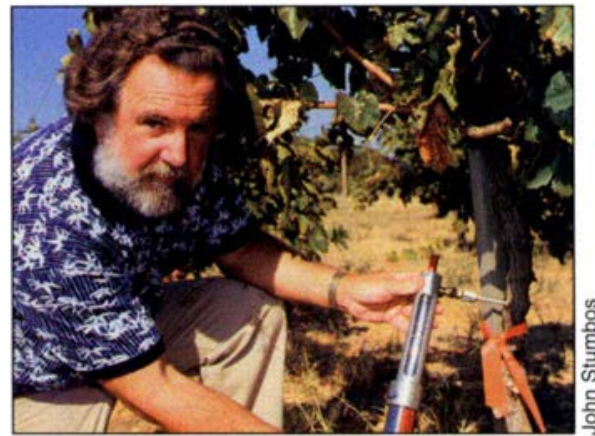

\section{New pest transmits Pierce's disease}

Pierce's disease, a lethal disease of grapevines first identified in California in the late 1800 s, is causing millions of dollars in damage to the state's vineyards. UC Berkeley scientists confirmed 20 years ago that the disease is caused by the Xylella fastidiosa bacterium, which attacks a plant's xylem, or water-conducting tissues, and eventually chokes off water and nutrient supplies.

Scientists have long known that the bacterium is transmitted to grapevines by blue-green sharpshooters, one of a subfamily of insects known as sharpshooter leafhoppers. More recently, the glassy-winged sharpshooter has emerged in California as another $X$. fastidiosa carrier, threatening not just Using a hand-held injection device, Bruce Kirkpatrick introduces nutrients into vines to protect them against infection. grapevines but other important crops and ornamentals (see Cal Ag March-April 1999).

Because the glassy-winged sharpshooters thrive on a variety of common plants, they have spread rapidly from Ventura to the Mexican border, and recently were found in the San Joaquin Valley. The half-inch-long brown insect feeds on plants infested with X. fastidiosa. After once acquiring the bacterium from an infected plant, the sharpshooter can transmit it to healthy plants throughout its life. As glassywinged sharpshooters expand in number and range, UC scientists across the state are racing to better understand the insect and its relationships to plant hosts.

\section{Pierce's disease ravages Temecula vines}

The glassy-winged sharpshooter, first identified as a major carrier of Pierce's disease in the Temecula Valley in 1997, has already caused an estimated \$1.2 million in damage in this southwest region of Riverside County. UC Riverside scientists are evaluating possible natural enemies to the glassy-winged sharpshooter in hopes of controlling the insect without pesticides. In addition to biological control strategies, they are investigating the use of pesticides and physical barriers to prevent the insects from flying into vineyards. Entomologists Matthew Blua and Rick Redak are exploring the use of a soil-applied insecticide that can be used by growers to reduce sharpshooter numbers and alter their feeding behavior while scientists work on slowing the spread of Pierce's disease.

\section{Pruning and freezing bacteria from vines}

Researchers in the laboratory of UC Berkeley professor Alexander "Sandy" Purcell have found that pruning and freezing may, in some cases, save grapevines afflicted with Pierce's disease. Purcell, one of California's leading experts on the devastating disease, has found that heavily pruning grapevines in winter helps eliminate the $X$. fastidiosa bacterium.

"Our early results with pruning are promising," Purcell says. "If a grower is faced with an infected crop, heavy pruning in the winter may mean he'll lose some crop, but he won't lose all of the time required to replace the vine. However, we need more data on how vine age and variety affect the success of pruning before we make specific recommendations."

Also in his lab, graduate researcher Helene Feil has found that freezing dormant vines in the lab can rid them of the disease.

"Although growers cannot intentionally freeze vines to cure plants of Pierce's disease," Purcell says, "these experiments provided unexpected indications that it is the vine's response to cold temperature, not just the temperature alone, that is necessary to kill the Xylella bacteria."

Purcell's lab is now trying to identify how freezing changes the grapevines so that the bacteria die.

\section{Micronutrients may prevent disease}

A UC Davis scientist is conducting experiments to determine whether infection by the bacterium responsible for Pierce's disease can be prevented by boosting grapevines' levels of essential plant micronutrients, such as zinc, iron and molybdenum.

"We've already established in the laboratory what concentrations are toxic to the bacteria," says plant pathologist Bruce Kirkpatrick. "What we need is to develop a system that gets those nutrients into the grapevine to protect it from infection." 
In an experimental vineyard at UC Davis, he has been looking at a number of methods of introducing the nutrients into vines - foliar applications to leaves, tiny plastic screws inserted into the vines, hand-held injection devices and irrigation drip lines.

The strategy is to protect the plants against infection, rather than to treat them after the fact. Once bacteria enter the root system, they become more difficult to treat because water travels up through infected xylem tissue toward respiring grape leaves. An advantage of inoculating vines with nutrients, Kirkpatrick says, is avoiding the stigma associated with antibiotic use. Encouraged by results from laboratory analyses, he is conducting field trials.

\section{UC task force to address Pierce's disease}

UC President Richard C. Atkinson has appointed a task force to mobilize and focus UC's scientific, technical and information outreach expertise to help growers combat Pierce's disease.

The UC task force will provide information and advice on research priorities to CDFA and Atkinson by Jan. 1, 2000. Representatives from CDFA, the American Vineyard Foundation, the U.S. Department of Agriculture and the California Legislature will be invited to participate in UC task force meetings.

\section{Room for Sonoma vineyards to expand}

The Sonoma County wine country has considerable room to grow, according to predictions of a new computer forecasting model developed by UC Berkeley scientists. The researchers mapped how much Sonoma County land is suitable for vineyard development, where these parcels are located and the environmental consequences should wide-scale conversion occur.

A booming wine market is driving Sonoma County's controversial vineyard expansion, says project director Adina Merenlender, a UC Berkeley conservation biologist.

"California wines have been extremely popular nationally and internationally," she says, "leading to increased demand for wine grapes."

In the current market, wine grapes can result in profits as high as $\$ 4,000$ per acre of vineyard land in full production, the new report said. The California wine crop was worth $\$ 2.1$ billion in 1996, more than triple its value just 8 years ago.
To make way for grapes, scenic hillsides harboring some of California's remaining oak woodlands are rapidly being cleared and planted with grapes, according to the UC Berkeley report. The computer model developed by Merenlender and UC Berkeley graduate student Emily Heaton predicts where future Sonoma vineyards might be planted.

The model crunched data drawn from a variety of Sonoma County land use and vineyard maps in addition to data provided by growers and county officials. The model revealed that despite the recent wave of planting, another 158,000 suitable Sonoma acres remain available for new vineyards. Should all the land be utilized in this fashion, $20 \%$ of the county ultimately could be covered with grapes, says Merenlender.

Her report points to vulnerable stands of native oak that, if eliminated, could fragment large forest patches that harbor wildlife. Some smaller wooded areas could be eliminated altogether by agricultural development.

Much of this oak woodland is located on hillsides historically considered marginal for agriculture because of slope, drainage, poor soil or other characteristics. But booming wine demand now is making growers reconsider these areas. At the same time, growers are coming under increasing scrutiny from urban neighbors, the environmental community and government agencies concerned about the effects of vineyards on natural resources, such as endangered species and native trees, Merenlender says. She works to collect data so informed decisions can be made.

"We were able to identify priority sites that, if protected, could prevent fragmenting the largest remaining forested areas in Sonoma County," Merenlender says.

CORRECTION: The classes of three pesticides were incorrectly identified on page 5 of the September-October 1999 issue: atrazine is a triazine pesticide, and aldicarb and carbofuran are carbamates. The U.S. Environmental Protection Agency is currently reviewing tolerances for organophosphate pesticides as well as pesticides from several other classes.
About 158,000 acres of oak woodlands remain available in Sonoma County for new vineyards. 